\title{
Online Education in Poverty-Stricken Counties
}

\section{Yihan Jin*}

The High School Affiliated to Yunnan Normal University, Kunming, Yunnan Province, China

*Corresponding author: Yihan Jin, cointreau_17@163.com

\begin{abstract}
Education problems in remote underprivileged regions in China have long been a prominent obstacle that inhibit the development of education equality. Among all solutions, internet education has the capacity to offset against the deficiencies of unequal distribution of educational resources. Analyzing the success of online education of Lushi County in Henan offers an opportunity of establishing a relatively more equal education system.
\end{abstract}

Keywords: Education equality, Internet education, Underprivileged mountainous counties

Publication date: October 2021; Online publication: October 29, 2021

\section{Backwardness of education in China's poor mountainous areas}

As of February 2018, there are 585 national-level poor counties in China. They are mainly scattered in Yunnan, Tibet, Guizhou, Sichuan, Xinjiang, and other central and western regions, most of which are concentrated at old revolutionary base areas, areas inhabited by the minorities, remote and border areas, as well as poverty-stricken areas. Table 1 illustrates the distribution and situations of poverty-stricken counties in Henan province, which has the third most numbers of poverty-stricken counties in China ${ }^{[1]}$.

Table 1. List of 53 poverty-stricken counties in Henan Province

\begin{tabular}{|c|c|c|c|}
\hline \multirow{2}{*}{$\begin{array}{l}\text { Provincially } \\
\text { administered } \\
\text { municipality }\end{array}$} & \multicolumn{2}{|c|}{ Key counties in the areas of poverty alleviation and development program } & \multirow{2}{*}{$\begin{array}{l}\text { Key counties designated } \\
\text { for poverty alleviation } \\
\text { through development by } \\
\text { the provincial government }\end{array}$} \\
\hline & $\begin{array}{c}\text { Key counties in contiguous } \\
\text { poverty-stricken areas with } \\
\text { particular difficulties }\end{array}$ & $\begin{array}{l}\text { Key counties included in the national } \\
\text { plan for poverty alleviation through } \\
\text { development }\end{array}$ & \\
\hline Kaifeng City & Lankao County & & \\
\hline Luoyang City & $\begin{array}{c}\text { Luanchuan County, Songxian } \\
\text { County, Luoning County, } \\
\text { Ruyang County }\end{array}$ & Yiyang County & Yichuan County \\
\hline $\begin{array}{l}\text { Pingdingshan } \\
\text { City }\end{array}$ & Lushan County & & Ye County \\
\hline Anyang City & & Hua County & Neihuang County \\
\hline Xinxiang City & & Qiufeng County & Yuanyang County \\
\hline $\begin{array}{l}\text { Xinxiang City } \\
\text { Luohe City }\end{array}$ & & Fan County, Taiqian County & $\begin{array}{l}\text { Puyang County } \\
\text { Wuyang County }\end{array}$ \\
\hline Sanmenxia City & Lushi County & & \\
\hline Nanyang City & $\begin{array}{c}\text { Nanzhao County, Zhenping } \\
\text { County, Neixiang County, and } \\
\text { Zhechuan County }\end{array}$ & Duqi County and Tongbai County & Fangcheng County \\
\hline
\end{tabular}

Continued on the next page 


\begin{tabular}{|c|c|c|c|}
\hline \multirow{2}{*}{$\begin{array}{l}\text { Provincially } \\
\text { administered } \\
\text { municipality }\end{array}$} & \multicolumn{2}{|c|}{ Key counties in the areas of poverty alleviation and development program } & \multirow{2}{*}{$\begin{array}{l}\text { Key counties designated } \\
\text { for poverty alleviation } \\
\text { through development by } \\
\text { the provincial government }\end{array}$} \\
\hline & $\begin{array}{l}\text { Key counties in contiguous } \\
\text { poverty-stricken areas with } \\
\text { particular difficulties }\end{array}$ & $\begin{array}{l}\text { Key counties included in the national } \\
\text { plan for poverty alleviation through } \\
\text { development }\end{array}$ & \\
\hline Shangqiu City & $\begin{array}{l}\text { Minquan County, Ningling } \\
\text { County, and Zhecheng County }\end{array}$ & Ju County and Yucheng County & Xiayi County \\
\hline Xinyang City & $\begin{array}{c}\text { Guangshan County, Xinxian } \\
\text { County, Shangcheng County, } \\
\text { Gushi County, Huaibin County, } \\
\text { and Handan County }\end{array}$ & & $\begin{array}{c}\text { Luoshan County, Xi } \\
\text { County }\end{array}$ \\
\hline Zhoukou City & $\begin{array}{l}\text { Huaiyang County, Shenqiu } \\
\text { County, Taikang County, } \\
\text { Shangshui County, and } \\
\text { Dancheng County }\end{array}$ & & $\begin{array}{l}\text { Xihua County and Fugou } \\
\text { County }\end{array}$ \\
\hline Zhoukou City & Xincai County & $\begin{array}{c}\text { Shangcai County, Queshan County, } \\
\text { and Pingyu County }\end{array}$ & $\begin{array}{l}\text { Miyang County, } \\
\text { Zhengyang County, and } \\
\text { Runan County }\end{array}$ \\
\hline Total & 26 & 12 & 15 \\
\hline
\end{tabular}

Source: Data comes from an online post, The Number of Poverty-Stricken Counties Nationwide in 2019

Among the top ten poverty-stricken counties in China (Kangbao County, Meigu County, Zhaojue County, Pengyang County, Maduo County of Qinghai Guoluo Tibetan Autonomous Prefecture, Dafang County of Bi Fang City, Xing County of Luliang City, Zhang County of Dingxi City, Zhouqu County, and Butuo County in Liangshan Yi Autonomous Prefecture), 8 counties are located in mountainous hinterlands. Among the $1400+$ counties in China, some have been plagued by poverty because of geographical disadvantages and frequent natural disasters. Due to challenging natural conditions, sparse population, and low living standards in hilly rural areas, education remains a major obstacle to their development. The outstanding ones include high dropout rate of students, poor academic performance, difficulty in improving students' quality, lack of arts education, poor working conditions for teachers, and high cost for teachers' training. In recent years, the development of education in mountainous areas has been improved by encouraging teachers to volunteer in remote mountainous areas. However, the scarcity of resources and the backwardness of education cannot be solved by education alone.

\section{The internet and poverty alleviation through education}

With the development of the internet and the expansion of online education, the disadvantage of scarce educational resources in remote mountainous areas has been countered to a certain extent. Improved infrastructures have sped up the connection of mountainous areas to the internet. Through corporate donations, private crowdfunding, and government subsidies, broadband and computers are now available in these areas. With the training of rural teachers, the education situations in mountainous areas are constantly improving. Among them is the remarkable achievement by Hujia Project, where supporting free online courses have been launched through Hujiang Online Class in primary and middle schools in 2015. It aims to change the traditional education through internet learning, realize the joint construction and sharing of online courses all over the country, as well as enable small-sized schools in remote areas to enjoy high-quality educational resources, thus making learning simpler, fairer, and happier. 
"There are serious problems in participating in a volunteer teaching program. Some volunteer teaching programs last only a few months, resulting in great problems. Many children do not know what the outside world is like, and they do not know there exist such excellent teachers. Only after the teachers leave, then they start to realize the gap between the faculties. They might not be able to leave the mountains in their lifetime, or they might not have the right for better education and even be more depressed ${ }^{[2]}$," according to $\mathrm{Fu}$ Cairui, the founder of Hujiang Online Class.

Hujiang Online Class desires to change the current situation of unequal education through the internet. How can people who are not in Beijing, Shanghai, other provincial capitals, or even in the cities improve themselves by studying? In regard to carrying out economic poverty alleviation in remote mountainous areas, the government considers that poverty alleviation through education is to block the intergenerational transmission of poverty by achieving universal literacy. High-quality education for poverty alleviation is an approach to blocking intergenerational transmission of poverty and an important starting point to improve self-sustenance among poor people. As long as a poor family has a child who is able to go to college, it is possible to lift a family out of poverty after that child's graduation. In order to control poverty, it is vital to first tackle the deficiency of knowledge and skills. In poor areas and among poor families, culture and knowledge hold the key to prosperity. There are still 580,000 poor people in Ningxia. According to the plan, 40,000 people are expected to be lifted out of poverty through education over the next five years, which means that high-quality education plays an important role in realizing the dream of moderate prosperity for tens of thousands of families in Ningxia.

The Chinese government attaches great importance to poverty alleviation through education and has taken a series of practical measures to promote the development of education in poverty-stricken areas. By developing education to help the poor, it is possible to help poor families alleviate poverty and become better-off, and at the same time train more outstanding talents, which would further stimulate social vitality. We are confident that poor areas would eventually enjoy fair and high-quality educational resources and children from poor families can create the future as well as eradicate poverty with their own efforts.

\section{A case study of Lushi County, Sanmenxia City, Henan Province}

\subsection{Profile of Lushi County}

By the end of 2014, there were still more than 70 million poor people in the rural areas in China. On November 23, 2015, the Political Bureau of the Communist Party of China (CPC) Central Committee deliberated and adopted the Decision on Winning the Fight against Poverty, ensuring that the rural poor would be lifted out of poverty by 2020. This is the most arduous task for the realization of general prosperity. Under the background of the country's general policy, on August 3rd, 2017, Lushi County went through several procedures, including application, qualification examination, meeting review, as well as spot check, and was finally confirmed by the Education Department of Henan as a pilot county of "Internet plus Education" to target poverty alleviation in Henan Province. Lushi County is the most remote national-level poverty-stricken county with the highest altitude, the largest area, and the smallest population density in Henan Province. There are 389 schools at all levels in Lushi County, and county-level schools have already entered the advanced ranks of Sanmenxia City. However, the lack of teachers and low teaching quality in township schools have seriously impeded the development of local education ${ }^{[3]}$. By taking information technology as a breakthrough, Lushi County founded the "153" system (illustrated in Figure 1): "1" refers to realizing educational balance as its central task; "5" refers to the use of five platforms, including information exchange platform, educational resource platform, video live webcast platform, video recording and webcasting platform, as well as CCtalk platform; "3" refers to the realization of three major goals, which include balanced resources, teachers' development, and students' success. 


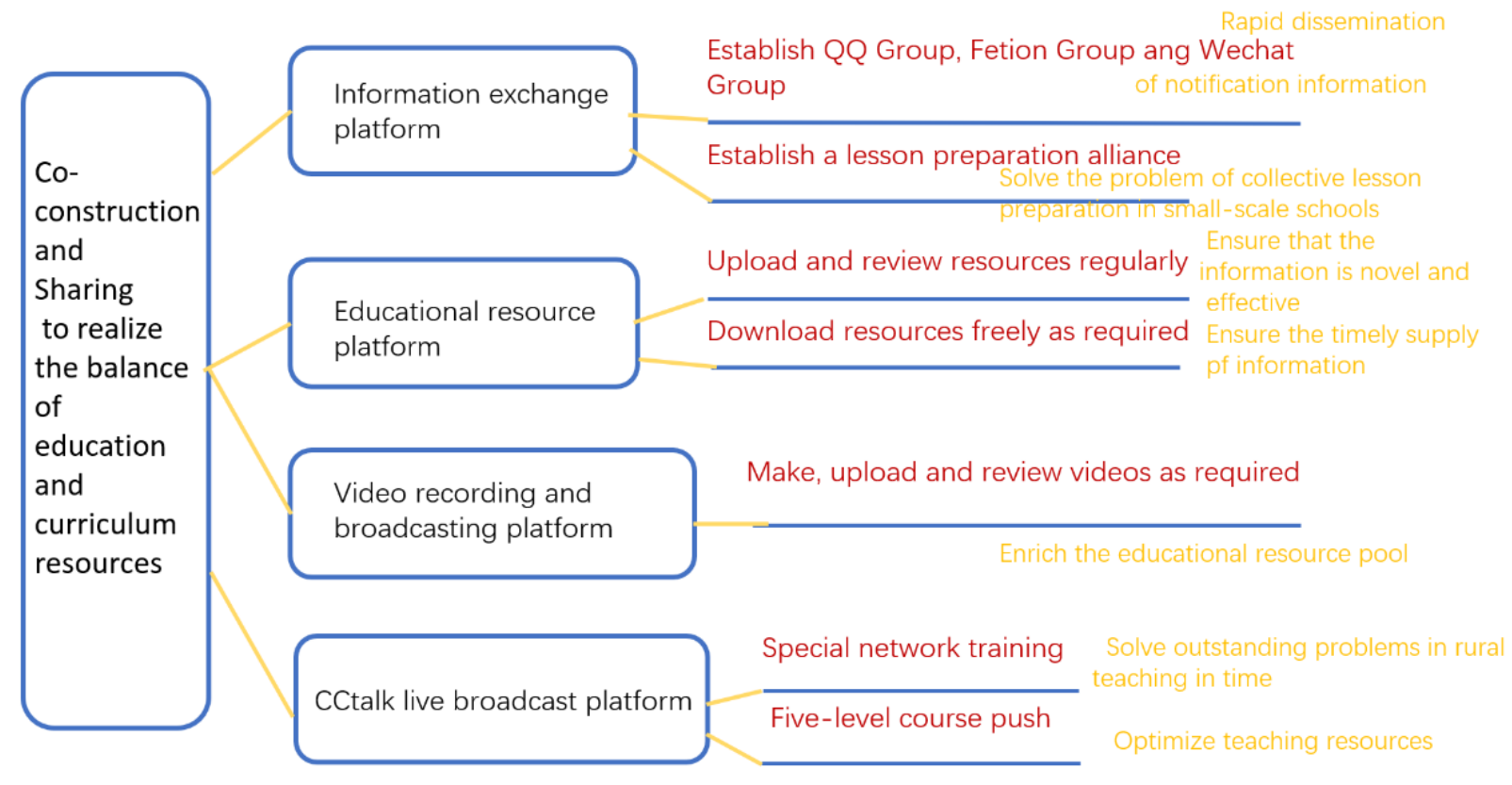

Figure 1. “153” system

Lushi County has a large area, and some villages can be as far as 100 kilometers away from the county seat. In view of that, it is expensive to organize trainings for teachers, and students are unable to attend classes normally. Based on online education platforms, Lushi County Education and Sports Bureau is conducting a two-way training program ${ }^{[4]}$. The first is to build 26 video conference rooms, basically covering all townships (towns). School headmasters and teachers would be able to participate in video conferences without leaving the school as well as keep abreast with new developments in education and teaching in the county. The second is relying on "CCtalk" and the use of smart phones to conduct teaching as well as research activities. In this way, the biannual teaching and research field meeting have changed into twice-a-week teaching activities, thus making teachers' learning more convenient, timely, and effective. On December 14th, 2016, Henan Daily reported on the practical exploration of "Internet Plus Education Targeted Poverty Alleviation" in Lushi County, Sanmenxia City, Henan Province over the past two months with the title of Leveraging the Internet to Develop Education to Help Poverty Alleviation in Lushi County [5].

Lushi County is a mountainous county with the largest area, smallest population density, highest altitude, and the westernmost geographical position in Henan Province. There are two vocational colleges, a high school, 26 junior high schools, 10 central schools, and 26 central primary schools in this county. It is worth mentioning that there are 199 teaching spots. As a national poverty-stricken county, an old revolutionary county, and a county that is deep into the mountains, Lushi County is facing the development dilemma of inconvenient transportation, scattered population distribution, lack of teachers, small scale, and scarce resources. If the intergenerational transmission of poverty is impeded by education, the most prominent shortcoming is that there are 63,134 impoverished people and 12,896 impoverished students in Lushi rural areas ${ }^{[6]}$.

Since the planning of the CCtalk network teaching and research in early September, Lushi County has built a teaching and research platform for collective activities among teachers; more than 20 platforms have been established for various disciplines, small-scale webcasts have been carried out frequently, and teachers have mastered the skill of live webcasting. Each school has established more than 30 class platforms with nearly 60 live courses, especially online music course platforms, thus solving the issue of shortage of music teachers in schools ${ }^{[7]}$. 
Initiated by the teaching and research unit of Lushi County Education and Sports Bureau and organized by the teaching and research staffs from various disciplines, teachers of all subjects in the county would carry out weekly collective teaching and research as well as briefly demonstrate on CCtalk, with nearly 1,000 participants in online teaching and research every time. Teachers of different subjects are able to participate in teaching and research at home using computers and smartphones as well as have in-depth discussions on teaching pedagogies via online forums. This teaching and research platform is also known as the "Khan Academy of Lushi" by frontline teachers in Lushi County. The CCtalk teaching and research platform has more than 5,000 online learning and 15,000 offline learning. In this county, webcasting, which mainly mirrors the demonstration of backbone teachers and is dominated by teachers as well as researchers, has begun.

The significance of education in reducing poverty lies in preventing its intergenerational transmission, but there are many problems to be addressed in remote mountainous areas. Lack of educational resources, difficulties in preparing lessons collectively in small-sized schools, lack of arts education, and high costs for teachers' training impede the undertakings of poverty alleviation in Lushi County. In order to solve the problems pertaining education in these mountainous areas, the local government is actively developing and utilizing the network platform to establish county-level and school-level resource pools while vigorously expanding the resource pool with the help of "One Teacher + One Excellent Course." Nowadays, in the county, teachers are able to download teaching resources from the resource pool by logging in to their own accounts and choosing the resources they need effortlessly.

The establishment of "Collective Lesson Preparation Alliance" has provided opportunities for teachers in small-sized schools to prepare lessons collectively across schools, townships, counties, and even cities. Some schools in Lushi County have also established alliances with famous schools in Xixia County and Luanchuan County by virtue of their geographical advantages, thus solving the problem of collective lesson preparation in small-sized schools.

By setting up a simple live webcast platform, teachers can webcast and watch it anytime and anywhere by using the CCtalk network platform. In November 2016, Lushi County Education Live Meeting was held in the remote Mutong Township Middle School. Three demonstration classes were webcasted live at six schools in Shahe, Panhe, and Mutong. The teachers in the county paid close attention to the live webcast in real time. In addition, the discussion was interactive, and overall, it was well received. Up to now, Lushi County has established more than 20 subject live webcast groups, 72 school live webcast groups, 226 school-subject live webcast groups, and 188 students and parents live webcast groups.

\subsection{From Ma'eryan model to Lushi model: Implementation of Lushi model}

There are 199 teaching spots in Lushi County, many of which have only one teacher. Ma'eryan Primary School in Wulichuan Town is more than 150 miles away from the county seat, with only 6 teachers and 48 pupils. It is one of the poorly equipped schools in Lushi County. In the spring semester of 2017, Ma'eryan Primary School carried out the "Five-level Curriculum" innovation practice under the intellect support from famous teachers in Sanmenxia City as well as the technical support from audio-visual education technicians in Lushi County and Hujia Project ${ }^{[8]}$.

"Five-level curriculum" refers to the introduction of different internet curriculum resources in the five grades of primary school to form a "super curriculum schedule." On this schedule, the teachers of "Happy Handicraft" are a team of famous artists from Sanmenxia Education Bureau who plan and prepare lessons collectively, and the host of "Rainbow Flower Morning Reading" is Shi Chaoli, a teacher from "Reading Changes China - Enlightener of the Year." The teams of art, science, finance, and business subjects are all from domestic first-line educational institutions, and the teacher for oral English lessons is Shelley, a teacher who is located far away in the United States. They have never set foot in Ma'eryan campus, but 
they would meet their students on a weekly basis through the online platform.

Table 2. The schedule for "Beautiful Countryside Primary School Online Public Welfare Classroom"

\begin{tabular}{|c|c|c|c|c|c|}
\hline \multicolumn{6}{|c|}{$\begin{array}{l}\text { The schedule for "Beautiful Countryside Primary School Online Public Welfare Classroom" } \\
\qquad \text { CCtalk group number: } 81508555\end{array}$} \\
\hline Time & Monday & Tuesday & Wednesday & Thursday & Friday \\
\hline \multirow[t]{5}{*}{ 0740-0800 } & & [Morning reading] & [Morning reading] & [Morning reading] & [Morning reading] \\
\hline & & "Rainbow Flower" & "Rainbow Flower" & “Rainbow & "Rainbow Flower" \\
\hline & & poetry & poetry & Flower" poetry & poetry \\
\hline & & (Lower section) & (High section) & (Lower section) & (High section) \\
\hline & & \multicolumn{4}{|c|}{ Group number: 81511222} \\
\hline $1120-1200$ & [Art] Grade 3-4 & [Music] Grade 1-2 & [Music] Grade 3-4 & [Art] Grade 5-6 & [Music] Grade 5-6 \\
\hline \multirow[t]{5}{*}{$1330-1410$} & & [Animation] Middle & [Animation] Senior & $1420-1500$ & \\
\hline & & and lower grades & grades & [Youth school] & \\
\hline & & & & Network literacy & \\
\hline & & \multirow{2}{*}{\multicolumn{2}{|c|}{ Group number: 81507591}} & Group number: & \\
\hline & & & & 81579514 & \\
\hline \multirow[t]{3}{*}{$1400-1440$} & & [Xia Jia’er art] & [Xia Jia’er art] & [Xia Jia’er art] & 24 solar terms \\
\hline & & Grade 5-6 & Grade 3-4 & Grade $1-2$ & Group number: \\
\hline & & & & & 326669 \\
\hline \multirow[t]{3}{*}{$14: 55-15: 35$} & [Art] Grade one & [Science] Middle & [Music] & [Music] & \\
\hline & & grades “Shark & Grade 5-6 & Grade 3-4 & \\
\hline & & Park" & & & \\
\hline
\end{tabular}

Source: Data obtained from Henan Daily

Based on Table 2, Ma'eryan model can be summarized as follows:

(1) first graders participate in the national integrated curriculum project experiment of Shenzhen South University of Science and Technology Experimental No.2 Primary School;

(2) second graders are introduced to Sanmenxia Foreign Language Primary School and "Beautiful Countryside" curriculum resources;

(3) third graders are introduced to the town-level synchronization course of the distribution base school of the town center school;

(4) fourth graders are provided with the provincial curriculum resource of "Rainbow Flower and Joy";

(5) fifth graders are offered the "Shark Park" high-quality curriculum resource and county-level curriculum resources.

In September 2017 alone, Ma'eryan Primary School joined 80 online "double-teacher classes." The students' works became the most beautiful scenery in the village primary school, transforming the village primary school into a colorful and melodious school. Small-sized rural schools deep in the mountains have advanced up to the frontline at the national level. Zhang Yong, a 59-year-old teacher, excitedly said, "The use of online curriculum resources has effectively made up for the shortcomings of insufficient curriculum resources and lack of teachers in various disciplines, including music, art, science, and other vulnerable disciplines, thus greatly promoting the overall development of the school and the improvement of students' 
comprehensive quality."

Immediately, the Ma'eryan model has been promoted in the county. The Teaching and Research Division of Lushi County improved on the occasion, made overall plans, and further introduced the Lushi model of "three classes" that can be used by the teaching spots in the county ${ }^{[9]}$.

(1) Synchronous online classes - The teaching and research staffs issue the curriculum schedule in advance, and the students in rural schools learn synchronously along with the quality courses by famous teachers in the county.

(2) Master teachers' classes - The teaching and research division of a county actively introduces the courses by famous teachers inside and outside the province, which are selected and used by local rural schools.

(3) Specially offered classes - Excellent teachers of music, physical education, and fine arts in urban areas subcontract curriculum construction tasks to organize teaching plans, while students in rural schools carry out learning activities based on videos.

The exploitation of curriculum resources, such as "Beautiful Countryside," "Rainbow Flower and Joy," and "Shark Park," has effectively made up for the shortage of curriculum resources and teachers inept in music, art, and science. The "five-level curriculum" is used interactively, focusing on application experiments, thus promoting the overall development of the school. Duan Xuefei, the headmaster of Ma'eryan Primary School, stated, "The CCtalk online platform is a big boost to our mountain village teaching spots." Wang Baofa, the headmaster of Wulichuan Town Central School, mentioned "The resources of the 'five-level curriculum' have enabled our children in the mountains to achieve simultaneous growth with the urban children."

Through nearly one year of practice, all 199 teaching spots in the county have gained full coverage of online curriculum resources. The teaching quality of a large number of teaching spots, such as Maohe Primary School in Shiziping Township, Lancao Primary School in Guanpo Town, Triangle Primary School in Shahe Township, and Shanghe Primary School in Wayaogou, has advanced by leaps and bounds, and the students' mindset has changed profoundly. Several teaching spots have forged effective cooperation with key schools in and outside the province, and family role exchange experience tour is about to kick off in the summer.

This teaching mode, which explores the joint construction and sharing of high-quality educational resources with the help of the internet that radiates to the teaching spots of primary schools in remote villages and towns, has successfully solved the problem of incomplete curricula in rural schools due to underperforming teachers and promoted a balanced development of high-quality education in line with the six core qualities of students' development: humanistic heritage, scientific spirit, learning to learn, healthy life, responsibility, as well as practice and innovation.

In order to help every student to enjoy high-quality educational resources, Lushi County has overcome economic difficulties, and all schools have realized the Class-to-Class Project. Duguan Middle School and Experimental Middle School, which have better conditions, are employing tablet computers and smartphones during lessons as well as implementing flipped classrooms.

During a research discussion, Jin Rui, the Deputy Director of Sanmenxia Education and Sports Bureau, mentioned, "The 'Internet Plus Education' platform has enabled Lushi, a poverty-stricken county, to achieve outstanding success in terms of a balanced development of education. The achievement, which is a necessary result, involved tremendous efforts made by the teaching and research community in Lushi County."

"A network cable can link thousands of households no matter how far they are from each other. Using the network, we have connected hundreds of teaching spots in the depths of the mountains. The take-off of 
Lushi education starts from here. Lushi education has broken the historical destiny. It is not too far from achieving a balanced education," commented Zhang Ruifeng, the Director of the County Education and Sports Bureau, at the "Internet Plus Education" promotion meeting in the county. It has set the tone for the development of education in Lushi County. With the help of "Internet Plus Education," the balanced development of education in Lushi is gradually becoming a reality.

\subsection{Project evaluation and feedback}

Lushi, a deep mountainous county in western Henan Province, is surrounded by 4,037 hills, both large and small, on a 4,004 square kilometers land. More than 2,400 rivers and streams originate from the mountains, crisscrossing its land, constituting its geographical features with mountains and deep valleys, forming insurmountable barriers to a sparse population of 380,000 local people with the lack of transportation links. As the water conservation area of the national key ecological area and the Middle Route of South-to-North Water Diversion Project, Lushi is one of the few counties in Henan Province that is not open to industrial development. The development and utilization of resources as well as the introduction of projects are greatly restricted, thus constraining its economic development. The socio-economic development in Lushi lags behind that of other regions in Henan province ${ }^{[10]}$. As of the beginning of 2016, there are still 19,645 poor families and 63,134 people living under the poverty line in the county, with a poverty incidence rate of $18.9 \%$. The task of poverty eradication is extremely arduous. Therefore, the provincial governor is directly responsible for the alleviation of poverty in Lushi County.

Through the Hujia Project, students are able to attend classes normally when they encounter bad weather in the mountains. On November 20th, 2001, heavy snow fell in Sanmenxia. In the past, primary and middle schools that are located in the deep mountains of Lushi County had to suspend classes for a day. However, the application of the online education platform represented by CCTalk has changed this situation. Under the organization of Sanmenxia Education and Sports Bureau, teachers from all counties (cities) and districts have "crowdfunded" 30 live webcast courses with rich content and various formats for primary and middle school students in the city. Through the platform, students are able to attend classes as usual with smartphones or computers at home; in addition, teachers are also able to communicate and raise questions at any time. Everything is the same except that these lessons are not in brick-and-mortar classrooms.

The final quality analysis meeting has always been the highlight of teaching research. Bai Bojing, a history teaching researcher, and Lu Jinhong, a morality and politics teaching researcher, participated in the "National Training" in Beijing. They conducted an education and teaching quality analysis meeting for ninth-grade teachers in Lushi County from thousands of miles away through a live webcast platform in Beijing Normal University. This training mode is welcomed by teachers. Zhang Yuqin, the only teacher in Sanjiao Village, Shahe Township, watched the session with relish every night using a smartphone sponsored by the County Education and Sports Bureau. Instead of watching television dramas, her eagerness for self-improvement through the CCtalk platform can be appreciated. Through the platform, Zhang Yuqin is able to watch high-quality videos recommended by the County Education and Sports Bureau as well as listen to lectures delivered by education experts from fist-tier cities like Beijing and Shanghai.

As for arts education, with the help of the staffs from the County Education and Sports Bureau, Ma Youcai, the headmaster of the teaching center in Guojiao Village, Shahe Township, became familiar with the operation of the online education platform after two days of exploration, and finally gained confidence in offering music and fine art lessons to the students. This was the first time in his 30-year teaching career [11]. 
The "Internet Plus Education" platform also led to major changes in the mode of teaching competitions in Lushi County. In December last year, contestants from schools more than 100 kilometers apart drew lots through CCtalk. During those two days, the contestants competed by means of live microlesson. The judges watched the competition via the computer, scored, and announced the results on the spot. Contestants were able to gauge the teaching situation of other teachers through videos and compare themselves with their peers, so that every teacher participating in the competition would be convinced of their own results. This openness and transparency have won unanimous praise from frontline teachers. Wang Wanqing, a mathematics teacher and researcher, mentioned, "This kind of competition is flexible. One of the advantages of this online competition is that it does not get in way of class hours. Many schools have regarded this competition as a teaching and research activity, which has achieved multiple goals." All quality class competitions in Lushi County have been conducted online ever since then.

Education mainly takes place in the classroom, but cultivation of students' interest and character is ubiquitous. What methods can be adopted to revitalize extracurricular activities so as to cultivate people? In Lushi County, the answer is to carry out comprehensive social practice activities during winter and summer vacations. Exemplifying the winter vacation practice in 2017, the Teaching and Research Division of the Education and Sports Bureau systematically planned out nine themes for social practice activities: Lushi Revolutionary Spirit Inheritance; Ecological Protection of Lushi; Traditional Culture of Lushi; Construction and Development of Lushi; Community Service and Charity Drive; Development and Application of Disciplines; Spring Festival Culture and Customs; Great Changes in Our County; Learning through Research and Interdisciplinary Integration.

On January 9, the teachers and students of the whole county responded unanimously as soon as the circular was issued. The teaching and research division under the Education and Sports Bureau of Lushi County received more than 160 programs, of which 103 of them passed the strict screening. In the month of February this year, Lushi County's comprehensive practical activities WeChat group was very active, with 103 live practical activities in three groups: primary school, junior middle school, and senior middle school, in which more than 3,000 teachers and students participated, with more than 2.3 million video clicks. Local students were able to interview the township officials and county magistrates during these activities, which greatly boosted their self-confidence. They were also given opportunities to host programs professionally. Throughout this process, students were able to learn how to conduct field surveys and statistical analyses without ambiguity.

What moved teachers even more was that they walked into nursing homes and interacted with the residents sincerely. The development of social practice activities does not only stimulate teachers' potential in organizing activities, but also encourage a large number of teachers to become online influencers and stimulate the unlimited creativity and practical skills among students in rural areas. After these activities, many teachers raved that the performance of the students was impressive, and their talents were given full play. "Under the guidance of teachers, no matter what kind of comprehensive practical activities students participate in, they would absorb positive energy, acquire real knowledge, and practice real skills," stated in deep affection by a parent. The activity based on the theme of "Let Environmental Ethics Education Find the Breeding Ground in Comprehensive Practical Activities" was rated as an excellent case for moral education in primary and middle schools in China.

\section{Conclusion}

\subsection{Advantages and characteristics of online education}

The internet is not restricted by time and space and is widely spread in various forms of digital media. These characteristics of the internet are made full use in online education. In this era of continuous 
technological progress, major online education platforms have developed rapidly, becoming the key to solving the uneven distribution of educational resources and the sustainable development of education.

The greatest advantage of online education to the development of education in mountainous areas is that it can break through geographical restrictions and solve the issues of backward transportation as well as scattered classrooms and schools in mountainous areas. In poor mountainous areas where arts education is inadequately offered, integration of technology in classrooms enhances students' learning experience. The implementation of technology also creates pathways for differentiated instruction to meet the unique needs of students as individual learners within a broader classroom climate. By combining online education with offline classroom, an online teacher collaborates with an assistant teacher in the classroom who acts as the tutor. Students can interact with the online teacher with the help of the assistant teacher, forming a model of "one classroom + two teachers." The co-teaching model can further enrich online courses and provide students with the opportunity to interact.

\subsection{Development of online education in mountainous areas}

Information technology has exerted great impact on the traditional teaching mode of rural primary schools. The internet is accessible to primary schools in the village, providing conditions for schools to complete their curricula and make full use of class hours. The co-teaching model has made up for the lack of professional skills among teachers and has injected new vitality into the dull classrooms in rural primary schools. When rural students are introduced to the Beautiful and Colorful Rural Classrooms of Hujia CoTeaching Program, they are given opportunities to learn singing, dancing, reading, writing, and the natural world at large. A relaxing, flexible, and efficient classroom environment makes instruction and learning more effective. Practice has proved that the miracle in rural primary schools can be created by virtue of the Hujia Project and the co-teaching model.

Longjing Primary School in Magu Town, Hezhang County, Guizhou Province is a village-level primary school. It was established in 1999 from the contributions of the local government and attentive people. It serves the neighboring areas like Longjing Village, Yutang Village, Lianhua Village, and a few students from other towns. Now the school has 6 classes, 212 students, 6 sets of classroom network equipment, and its infrastructure equipment meets the basic needs of online courses. Longjing Primary School is located on an expansive hillside, with a beautiful environment, where flowers and birds are seen during spring, trees in summer, fruits in autumn, and snow in winter. Thanks to the perseverance of the teachers and the students' hard work, Longjing Primary School in Magu Town, Hezhang County, Guizhou Province won the honorary title as one of the "Top Ten Most Beautiful Rural Primary Schools." This small, beautiful, and excellent village primary school has stood out among thousands of its equals. Longjing Primary School has found its own "path" of development in the information age through the promotion of the Hujia Project ${ }^{[12]}$.

From Ma'eryan model to Lushi model, the development of online education has gone from pilot project to maturity. With the joint efforts of the local government and educators, it took only a year to realize the full coverage of online education in this region, benefitting all 199 teaching spots. This mode of infrastructure upgrading plus online education is applicable to backward mountainous areas. Compared with constantly hiring teachers and building new schools, it is more important to improve the quality of education. Online education makes it possible for education in mountainous areas to develop in a sustainable manner in the long run. Online education does not only change the way of learning in mountainous areas, but also broaden students' horizons, provide more choices, share educational resources from developed areas, and promote the fair development of education to a certain extent. In a word, online education creates infinite possibilities. It is not only an important breakthrough technology in the development of human society, but also an innovative solution to future problems in education. 


\section{Disclosure statement}

The author declares that there is no conflict of interest.

\section{References}

[1] College Entrance Examination Network, 2019, The Number of Poverty-Stricken Counties Nationwide in 2019. Gaokao Shengxue Net. http://www.creditsailing.com/HuaDangZiXun/743860.html

[2] Chubei Net, 2017, Fu Cairui: Why Do We Insist on Doing Hu Jia Plan?. Phoenix New Plan. https://news.ifeng.com/a/20171102/52913710_0.shtml (updated February 11, 2017).

[3] Technology Helps Lushi County to Achieve Balanced Development of Education. https://dx.eduyu n.cn/html/qy1/20181203/296.html

[4] Mutual Plus Plan, 2016, Internet + Education Targeted Poverty Alleviation. How Do National-Level Poverty-Stricken Counties Practice Online Intellectual and Educational Poverty Alleviation?. Weixin.qq. https://mp.weixin.qq.com/s?_biz=MzI1NDE0NTk0Ng==\&mid=2650422306\&idx=1\&s $\mathrm{n}=42 \mathrm{fa} 223 \mathrm{e} 990 \mathrm{ab} 5 \mathrm{ad} 3 \mathrm{a} 1 \mathrm{aeb} 3 \mathrm{cc} 671904 \mathrm{~d} \& \mathrm{chksm}=\mathrm{f1c} 738 \mathrm{~d} 7 \mathrm{c} 6 \mathrm{~b} 0 \mathrm{~b} 1 \mathrm{c} 1 \mathrm{ba33e} 47 \mathrm{bf90c10726bdf121306}$ 8c36938a0062e729710f978d90e5e89359\&scene=21\#wechat_redirect

[5] Henan Daily, 2016, Leveraging on "Internet +" Lu's Educational Poverty Alleviation Takes a Shortcut. Weixin.qq. https://mp.weixin.qq.com $/ \mathrm{s}$ ? biz=MzI1NDE0NTk0Ng==\&mid=2650422520\&idx $=1 \& \mathrm{~s}$ $\mathrm{n}=\mathrm{d} 7 \mathrm{~d} 5 \mathrm{e} 4152 \mathrm{e} 6 \mathrm{~d} 9 \mathrm{c} 98 \mathrm{e} 116763602363062 \& \mathrm{chksm}=\mathrm{f1c} 7380 \mathrm{dc} 6 \mathrm{~b} 0 \mathrm{~b} 11 \mathrm{~b} 66 \mathrm{~d} 4 \mathrm{~d} 7 \mathrm{a} 417 \mathrm{~d} 5 \mathrm{~b} 46 \mathrm{c} 93 \mathrm{cece} 236$ d6dccdf4f2616d46ffdf2e22e9510bd93fb\&scene=21\#wechat_redirect (updated December 24, 2016).

[6] Han Shiwen, 2017, How to Realize Overtaking in a Curved Road in a Poor Country. China Education News. http://www.jyb.cn/zgjsb/201707/t20170712_704734.html (updated December 7, 2017).

[7] Lushi County Was Recognized as a Pilot County of "Internet Plus Education" Targeted Poverty Alleviation in Henan Province. Lushi County People's Government 2015. http://www.lushixian.go v.cn/pageView/article.html?pageNum=8\&lmid=2344\&wzid=540661 (updated September 11, 2017).

[8] Han Wang (eds.), 2017, Fu Cairui Launched a Mutual + Plan to Use the Internet to Support Education to Help Rural Education Development. Netease Home. https:/www.163.com/news/article/D2PVL1E4 00014AEE.html (updated September 11, 2017).

[9] Oasisli (eds.), 2017, Internet Education Support Is in Action: "Hu Jia Plan" Has Spawned the "Lushi Mode" Education Fair Practice. Tencent. https:/edu.qq.com/a/20171031/038586.htm (updated October 31, 2017).

[10] China's Rural Revitalization, 2020, Secretary of Lu's County Party Committee: The County with the Highest Incidence of Poverty in Henan Province Has Lifted Out of Poverty Like This. The Paper. https://m.thepaper.cn/baijiahao_6241053 (updated February 29, 2020).

[11] Guixin Wuye, 2016, Lushi Educational Poverty Alleviation Takes a Shortcut. Henan Newspapering Network Center. http://newpaper.dahe.cn/hnrb/html/2016-12/14/content_103351.htm (updated December 14, 2016).

[12] Fu Zongnian, 2019, “Double-Teacher Classroom” Injects New Vitality into Village Primary School Teaching. https://www.jianshu.com/p/a4aee158cda8 (updated January 27, 2019). 